\title{
Effects of Garcinia hydroxybiflavanonol-1 (GB1) isolated from Garcinia kola Heckel (Guttiferae) seeds on reproductive toxicity induced with cadmium chloride $\left(\mathrm{CdCl}_{2}\right)$ in male Wistar rats
}

\author{
Uwagie-Ero E. A. ${ }^{1,}$ and Nwaehujor C. O. ${ }^{2}$ \\ ${ }^{1}$ Department of Surgery, Faculty of Veterinary Medicine, University of Benin, Benin City, Nigeria. \\ ${ }^{2}$ Department of Biochemistry, Faculty of Basic Medical Sciences, P.M.B. 1115, University of Calabar, Nigeria. \\ *Corresponding Author: edwin.uwagie-ero@uniben.edu
}

https://doi.org/10.36263/nijest.2020.01.0166

\begin{abstract}
To examine the effects of Garcinia hydroxybiflavanonol-1 (GB1) isolated from seeds of Garcinia kola Heckel (Guttiferae) on reproductive toxicity induced with cadmium chloride $\left(\mathrm{CdCl}_{2}\right)$ in male Wistar rats. Rats were randomly assigned to Groups 1 to $3(n=12)$ as follows; $A$ : control, $B: \mathrm{CdCl}_{2}$ only group, $\mathrm{C}$ : $\mathrm{CdCl}_{2}+\mathrm{GB1}$. Cadmium toxicity was induced by including $2.5 \mathrm{mg} / \mathrm{kg}$ of $\mathrm{CdCl}_{2}$ into the rats' drinking water and GB1 was dissolved in $0.5 \%$ Tween 20 and administered per os daily for 90 days. Four (4) animals from each group was humanely euthanized every 30 days. The testes were exteriorized and sperm cells collected from the caudal epididymis for analysis and histology. The result showed accumulation of Cadmium $(C d)$ in the testes of Wistar rats and a significant decrease $(p<0.05)$ in sperm count and sperm motility in Group B compared to Groups A and C. There was also a significant increase $(p<0.05)$ in immotile sperm count, headless sperm count and sluggish sperm count in Group B. Histology results revealed that $\mathrm{CdCl}_{2}$ significantly reduced the volume of spermatozoa in the seminiferous tubules and resulted in reduced spermatogenesis observed, in reduced number of sperm counts and histology. Amelioration with GB1 restored the testicles to normal spermatogenic activities after 90 days of treatment.
\end{abstract}

Keywords: Garcinia kola seeds, Garcinia hydroxybiflavanonol-1 (GB1), cadmium chloride $\left(\mathrm{CdCl}_{2}\right)$, toxicity, Wistar rats, male reproduction.

\subsection{Introduction}

Bioaccumulation of cadmium; a ubiquitous non-degradable environmental pollutant that enters the food chain is an issue of severe global concern. Its environmental accumulation is due to its increased industrial usage in mining, electroplating, dyeing, paints, just to mention a few, as well as its occurrence in agricultural fertilizers (Renugadevi and Prabu, 2009; Newairy et al., 2007). Cadmium is one of the elements found to damage antioxidant systems in mammals (Uwagie-Ero et al., 2019). In general cadmium pollution results from natural weathering of materials, forest fires and volcanoes, but much larger amounts are released by human activities (Morrow, 2001). Cadmium chloride used in photography, photocopying, dyeing, calico printing, vacuum tube manufacture pigment production, galvanoplasty, lubricants, ice-nucleation agents, drinking pipes and manufacture of special mirrors (Herron,2003) may easily enter the environment. Long-term ingestion of large amounts of cadmium has been observed in Japan (Massanyi et al., 2005). The exceptionally long half-life of cadmium in the human body of about 30 years (Kjellstrom et al., 2011), emphasizes the need for the effective assessment and treatment of cadmium toxicity. The reproductive potential of species and their survival have been threatened by an increased industrial and environmental contamination ( $\mathrm{Bu}$ et al., 2011). Cadmium has been reported to contribute to male infertility via reducing sperm quality in humans and rats (Mendiola et al., 2011; Roychoudhury et al., 2010).

Oxidative stress is a condition associated with an increased rate of cellular damage induced by oxygen and oxygen derived oxidants commonly known as reactive oxygen species (Zikic et al., 1998). The 
cellular damage in the gonads may be due to an improper balance between ROS (reactive oxygen species) generation and scavenging activities (Pajavic and Saicic, 2008). Exposure to cadmium intoxication has been reported to cause damage to the reproductive tissues and gonads, cadmium toxicity targets the testes both in low and high levels of exposure (de Angelis et al., 2017). It is found to accumulate in the testis, resulting in oxidative stress and germ cell apoptosis, as well as suppression of spermatogenesis (Nna et al., 2017). To ameliorate cadmium toxicity and to prevent oxidative stress, natural products may be useful. The biflavinoid has been shown to improve negative effects of oxidative stress in lipids, proteins and DNA (Farombi et al., 2013).

Previous phytochemical investigations of G. kola resulted in the isolation of cycloartenol, 24methylene-cycloartenol and kolanone (Hussain et al., 1982) from the light petroleum extract and C3/8"-linked hydroxybiflavanonols from the ethylacetate extract of the seeds (Sonnenbichler et al., 1986).

The aim of the present study was to investigate the ameliorative effects of administration of Garcinia hydroxybiflavanolol-1 on the reproductive health of chronic cadmium chloride intoxicated male Wistar rats.

\subsection{Materials and Methods}

\subsection{Chemicals}

Cadmium chloride $\left(\mathrm{CdCl}_{2}\right)$, Tween20 used for this study were purchased from Sigma-Aldrich Co. (St Louis, MO, USA). All other reagents were of analytical grade.

Mature seeds of Garcinia Kola were purchased from a local Market in Calabar, and the seeds were identified by Dr. Michael Ekpo of the Department of Botany, University of Calabar, Nigeria. A voucher specimen was deposited in the herbarium of the department of Biochemistry, University of Calabar, Nigeria.

\subsection{Extraction, fractionation of crude extract and Isolation of Garcinia hydroxybiflavanonol-1 (GB1)}

This was done as described by Nwaehujor et al (2013) and isolates were identified as previously described Sonnebichler et al (1986).

\subsection{Laboratory animals}

Thirty-six (36) pathogen-free male adult Wistar rats (10 weeks old) and weighing $170-190 \mathrm{~g}$ were obtained from the animal house of the Department of Biochemistry, College of Medical Sciences, University of Calabar, Nigeria. They were acclimatized for 7 days and were allowed ad libitum access to feed and water. Experimental animals were kept in accordance with the guidelines for animal care as contained in the animal ethics handbook of the Faculty of Basic Medical Sciences, University of Calabar, Nigeria.

\subsection{Experimental design for Reproductive Toxicity assay}

The rats were randomly assigned to Groups 1 to $3(\mathrm{n}=12)$ as follows; A: control, $\mathrm{B}$ : $\mathrm{CdCl}_{2}$ only group, $\mathrm{C}: \mathrm{CdCl}_{2}+\mathrm{GB} 1$ group. Group A rats were orally administered distilled water only, group $\mathrm{B}$ rats received $\mathrm{CdCl}_{2}(2.5 \mathrm{mg} / \mathrm{kg}$ b.w. in drinking water), group C rats were treated with GB1 (2 mg/kg b.w./daily) and $\mathrm{CdCl}_{2}\left(2.5 \mathrm{mg} / \mathrm{kg}\right.$ b.w. day) in drinking water. Cadmium chloride $\left(\mathrm{CdCl}_{2}\right)$ was dissolved in the drinking water at a dose of $2.5 \mathrm{mg} / \mathrm{kg}$ and GB1 were dissolved in $0.5 \%$ Tween20 and administered per os for 90 days. The dose for $\mathrm{CdCl}_{2}$ was chosen from previous studies by El-Demerdash et al (2004) and Alkhedaide et al (2016) for cadmium chloride, and Nwaehujor et al (2013) for GB1. After every 30 
days, 4 animals from each group was humanely euthanized under chloroform anesthesia. The experiment lasted for 90 days.

The testes were immediately exteriorized through a mid-caudoventral abdominal incision with sterile scalpel blade. Sperm cells were then collected from the caudal epididymis (Oyeyemi et al., 2011).

This was done by removing the caudal epididymis from the right testes and blotting with filter paper. The caudal epididymis was immersed in $5 \mathrm{ml}$ formal-saline in a graduated test tube and the volume of fluid displaced was taken as the volume of the epididymis. The content from the epididymis and the content from the caudal epididymis were poured into a ceramic mortar and homogenized into a suspension from which the sperm count was carried out using the improved Neubauer haemocytometer under the microscope (Zemjanis, 1977).

A small drop of sperm suspension was collected with fluid from the caudal epididymis via scalpel and dropped onto a slide. The diluents (buffered $2.9 \%$ sodium citrate solution) kept at $37{ }^{\circ} \mathrm{C}$ was added to the sperm suspension until the desired dilution was obtained. Sperm motility was assessed by the method described by Zemjanis (1977). The motility of the epidydimal sperm was evaluated microscopically 2 - 4 minutes of their isolation from caudal epididymis and later expressed as percentages.

This was assessed by adding 2 drops of warm eosin nigrosin stain to the semen on a pre warmed slide, a uniform smear was made and dried with air and the stained slide was immediately examined under the microscope using $\mathrm{x} 400$ magnification. The live sperm cells were unstained while the dead sperm absorbed the stain. The stained and unstained were counted and the percentage calculated (Oyeyemi et al., 2011).

\subsection{Testicular histopathology}

Testes of each rat were fixed in bouins fluid, passed through ascending series of ethanol and then through xylene and embedded to paraffin wax. The tissues were sectioned at the thickness of haematoxylin and eosin and mounted. All sections were examined under light microscope at x100 and x400 magnifications. Photomicrographs of the lesions were taken for observation and documentation of histopathologic lesions.

\subsection{Data analysis}

The mean and standard error of mean were calculated for the semen characteristics and hormonal assay and were presented in percentages. One-way ANOVA (analysis of variance) and Duncan multiple comparison test was done using statistical package for social science (SPSS) v20 for Windows to establish any significant difference at $95 \%$ confidence interval. Values of $p<0.05$ were considered significant.

\subsection{Results and Discussion}

\subsection{Identification of isolate}

Garcinia hydroxybiflavanonol-1, GB1 was identified as previously described by Madubunyi (1983) and Sonnenbichler et al (1986), as shown in Figure 1. GB1 have shown antioxidant and anti-inflammatory potentials in pervious experiments. GB1 alone had significant quantity that was enough for animal treatment for the number of days the experiment lasted and so, was used for the experiment. 


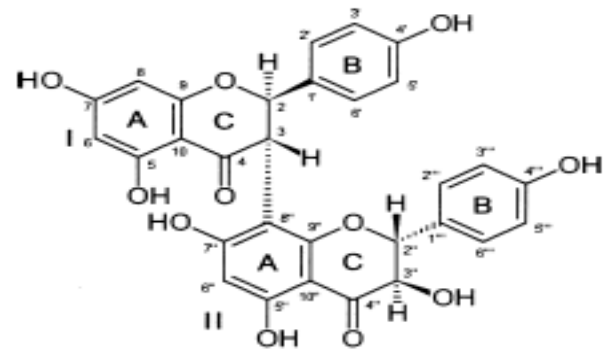

Figure 1: Chemical structure of Garcinia hydroxybiflavanonol-1

\subsection{Sperm morphology}

The chosen dose for cadmium chloride was shown to cause significant oxidative stress in various tissues of the body (El-Demerdash et al., 2004; Alkhedaide et al., 2016) while that of GB1 showed significant antioxidant effect (Nwaehujor et al., 2013; Uwagie-Ero et al., 2019). Results of this study showed a significant $(p<0.05)$ reduction in sperm count, sperm motility, number of morphologically normal spermatozoa and a significant $(p<0.01)$ increase in the number of morphologically abnormal spermatozoa in Wistar rats exposed to cadmium chloride when compared to control and GB1-treated groups (Figure 2a-d).

a)

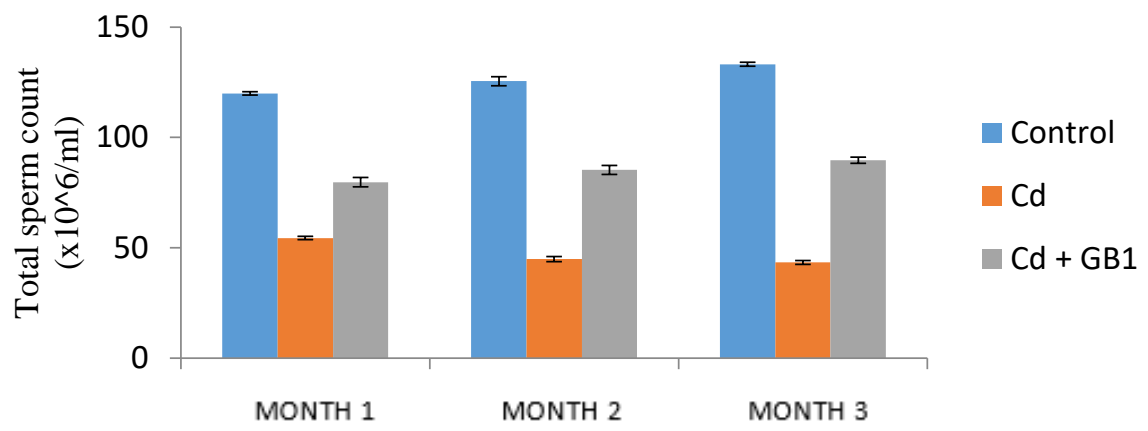

b)

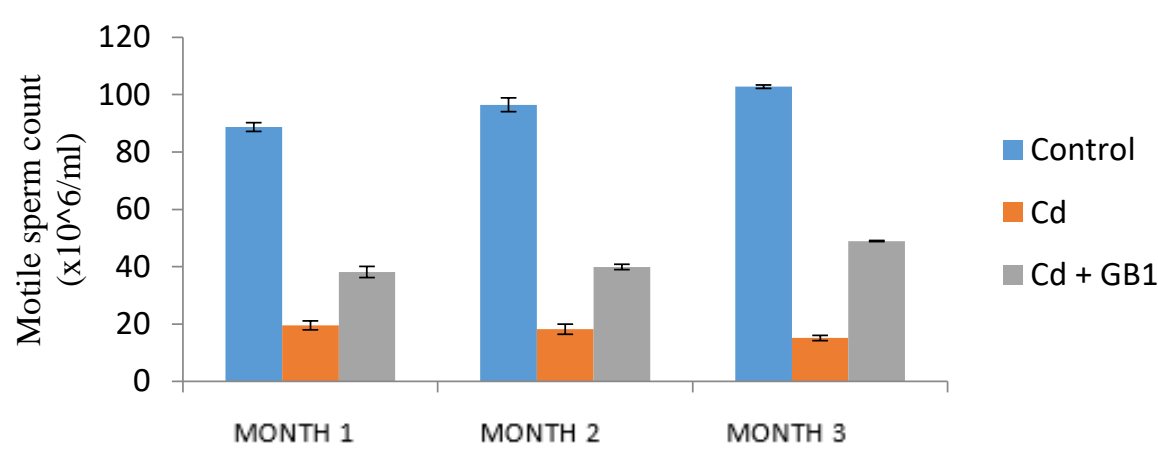

c)

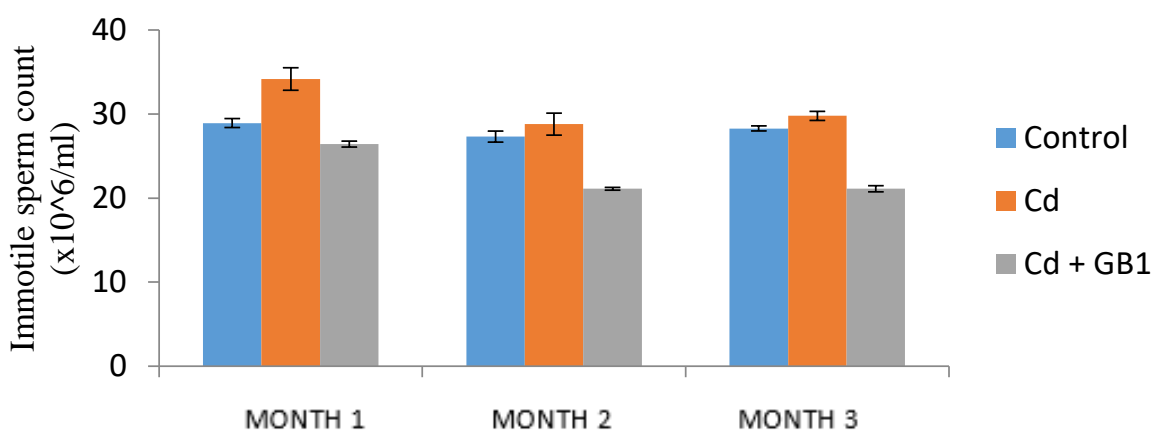


d)

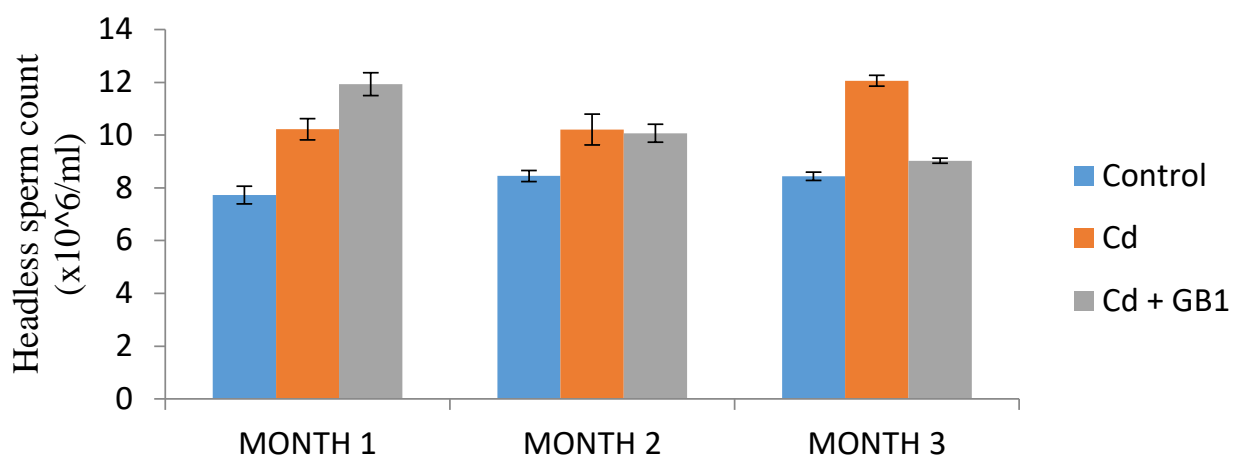

Figure 2: Ameliorative effect of Garcinia hydroxybiflavanonol-1 on cadmium-induced toxicity on a) total sperm count, b) motile sperm count, c) immotile sperm count and d) headless sperm count.

\subsection{Testicular histopathology}

Histologically, testes of Wistar rat revealed that; at month one the control and treated groups (Figure 3) showed no visible lesion (Figure 3C and $\mathrm{C} 1$ ) when compared with the control group (Figure $3 \mathrm{~A}$ and A1). However there was mild erosion of the germinal epithelium in the group treated with $\mathrm{CdCl}_{2}$ as seen in (Figure 3B and B1). The structural integrity of the interstitium was intact across the groups.
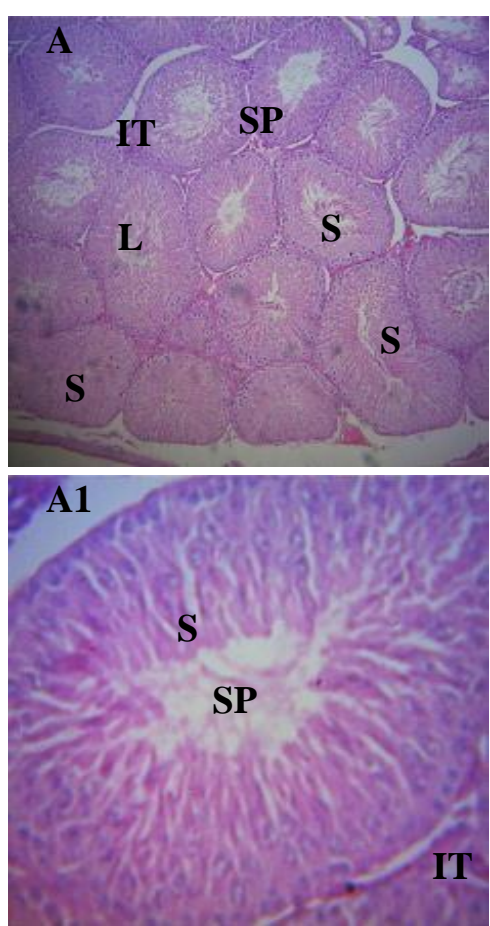
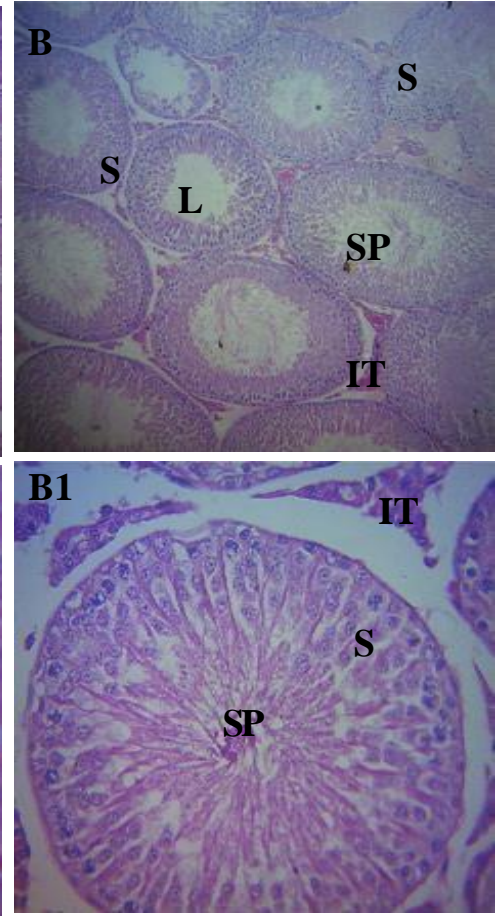
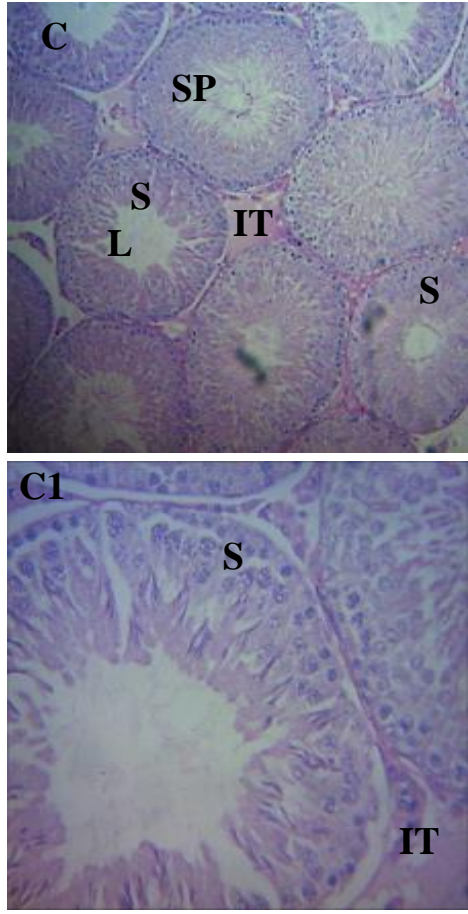

Figure 3: Photomicrograph of Wistar rat testis showing the control group (A and A1) and the $\mathrm{CdCl}_{2}$ treated group (B and B1) and GB1 treated group (C and C1) at month 1 with the sperm cells (SP) in the lumen (L), the interstitial tissue (IT) of the seminiferous tubules (S).

In the treated group (B and B 1), there was no visible lesion observed in GB1 treated group (C and $\mathrm{C} 1)$ when compared with the control group ( $\mathrm{A}$ and $\mathrm{A} 1$ ). However, there was mild erosion of the germinal epithelium in the group treated with $\mathrm{CdCl}_{2}$ (B and $\mathrm{B} 1$ ). Note the intact structural integrity of the interstitial tissue across the groups.

At month 2 however, the structural integrity of the interstitial tissues in the $\mathrm{CdCl}_{2}$ treated group was severely compromised with widening of the interstitial space (Figure 4 - B and B1) but this was mild in 
the Garcinia hydroxybiflavanonol-1 treated groups (Figure 4 - $\mathrm{C}$ and $\mathrm{C} 1$ ) as compared to the control (Figure 4 - A and A1).

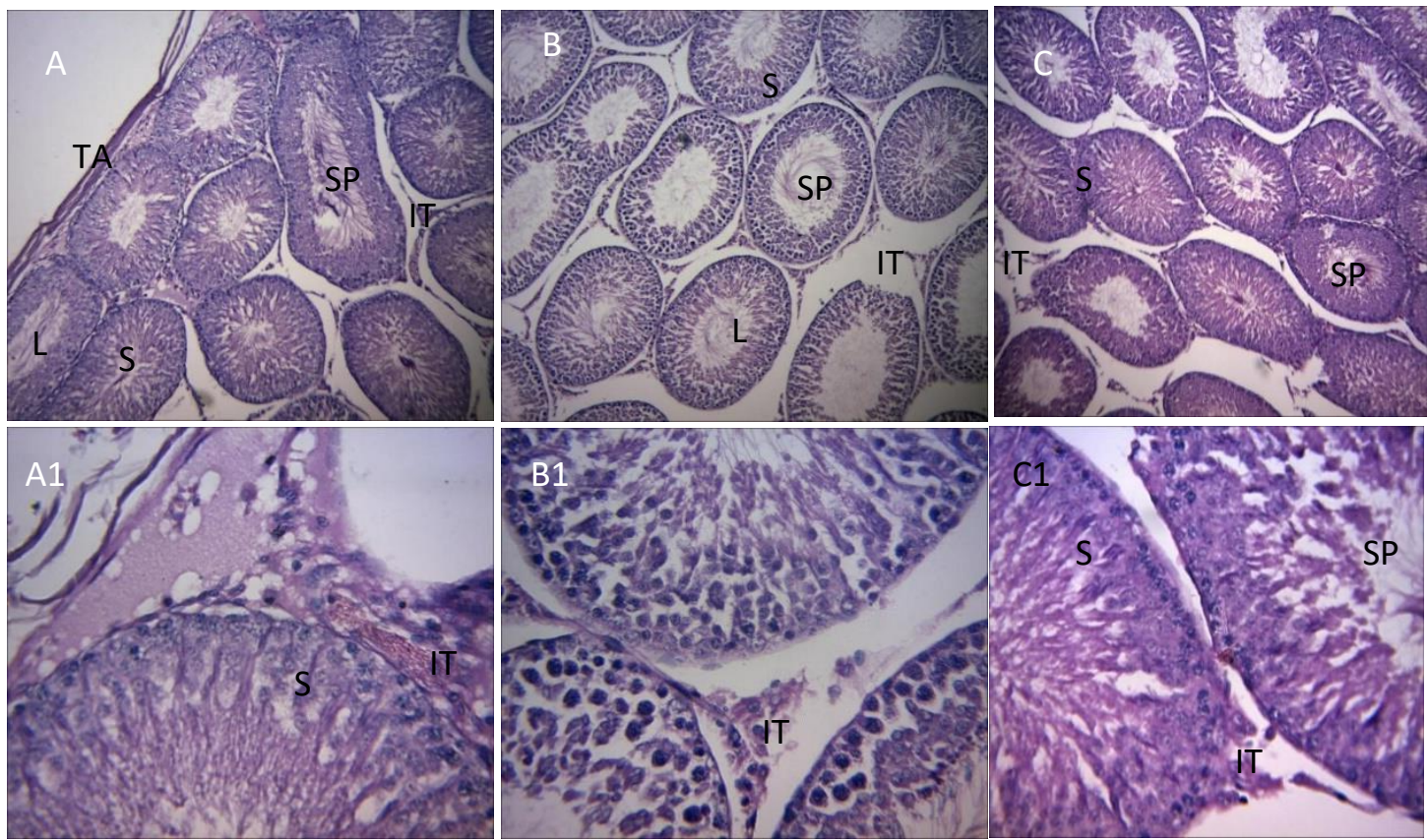

Figure 4: Photomicrograph of Wistar rat testis showing the control group ( $\mathrm{A}$ and $\mathrm{A} 1$ ), $\mathrm{CdCl}_{2}$ treated group (B and B1), and GB1 treated group (C and C1) and at month 2, with the sperm cells (SP) in the lumen (L), the interstitial tissue (IT) of the seminiferous tubules (S).

In the treated group (B and B1), there was no visible lesion as observed in ( $\mathrm{C}$ and $\mathrm{C} 1$ ) when compared with the control group (A and A1). However, compromise in the structural integrity of the interstitial tissue in the $\mathrm{CdCl}_{2}$ and GB1 treated groups compared to the control was observed. This compromise is pronounced in group (B and B1). By the third month, there was severe interstitial edema and spermatogenic arrest in the $\mathrm{CdCl}_{2}$ treated group (Figure 5 - B and B1), whereas no visible lesion was observed in GB1 treated group (Figure 5 - $\mathrm{C}$ and $\mathrm{C} 1$ ) when compared with the control group (Figure 5 $\mathrm{A}$ and $\mathrm{A} 1)$.
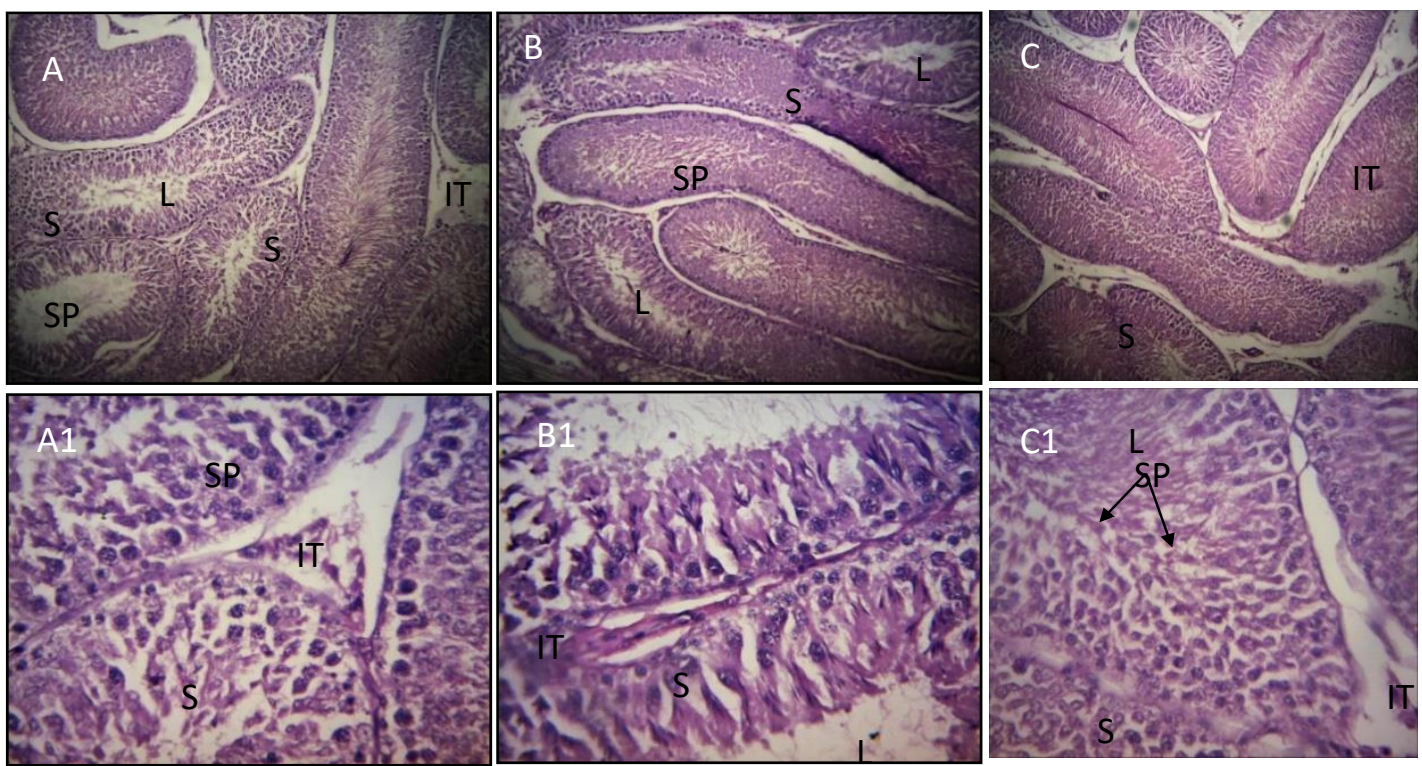

Figure 5: Photomicrograph of Wistar rat testis showing the control group (A and $\mathrm{A} 1$ ), $\mathrm{CdCl}_{2}$ treated group (B and B1) and GB1 treated group (C and C1) at month 3, with the sperm cells (SP) in the lumen (L), the interstitial tissue (IT) of the seminiferous tubules (S). 
There was no visible lesion observed in GB1 treated group ( $\mathrm{C}$ and $\mathrm{C} 1)$ when compared with the control group (A and A1). However, severe compromise in the structural integrity of the interstitial tissue in the $\mathrm{CdCl}_{2}$ treated group (B and B1) was observed. This was mild in the GB1 treated group compared to the control.

\subsection{Discussion}

Spermatogenesis is a complex series of differentiation process that can be disrupted by toxic chemicals, heavy metals, heat, radiation, hormone deficiencies and deficiency in the immune system (Akunna et al., 2014; Khanna et al., 2016). Results of this study showed a significant $(p<0.05)$ reduction in sperm count, sperm motility, number of morphologically normal spermatozoa and a significant $(p<0.01)$ increase in the number of morphologically abnormal spermatozoa in Wistar rats exposed to cadmium chloride when compared to control and GB1-treated groups (Figure 2a-e). These results are in line with earlier studies which showed a degenerative reaction of testicular and epididymal tissues to cadmium thereby contributing to male infertility by reducing sperm quality in humans and rats (Mendiola et al., 2011; Roychoudhury et al., 2010).

Cadmium has been reported to cause spermatotoxicity either by causing a disruption of the hypothalamic-pituitary axis or by direct effect on spermatogenesis through oxidative damage (Roychoudhury et al., 2010; Xu et al., 2001). Since sperm cells and testicular leydig cell mitochondria are common body cells that are susceptible to cadmium-induced oxidative stress the latter represents the major factor (Khanna et al., 2016). Cadmium is known to affect reproductive organs (Massanyi et al., 2000; Toman et al., 2002). In the blood and tissues, Cadmium stimulates the formation of metallothioneins and reactive oxygen species (ROS), thus causing oxidative damage in erythrocytes and in various tissues. This produces a loss of membrane functions (Sakar et al., 1998).

It has been shown that GB1, an atropisomer in nature (Sonnenbichler et al., 1986) is the major component of G. kola seed (Cotterhill et al, 1978). This agent stimulates the synthesis of ribonucleic acids and proteins in primary cultured rat hepatocytes (Madubunyi, 1983; Cotterhill et al, 1978). Although the stimulatory effect on cell metabolism gives an insight into its mode of action, it does not fully explain the mechanism of action against such totoxins like D-galactosamine and the toxic constituents of the death-cup toadstool Amanita phalloides, especially phalloidin.

Testicular histology showed that the interstitial cells had a high degree of sloughing off and there was interstitial oedema in the $\mathrm{CdCl}_{2}$-treated group (Figure 3) in the first month of treatment. No visible lesions were seen in the seminiferous tubules in the germinal epithelium but there was significant reduction in the accumulation of spermatozoa in the lumen of the seminiferous tubules (Figure 4) by month 2. Interstitial cell integrity was improved in GB1-treated and the control groups, and the germinal epithelial cells did not show any signs of degeneration by the third month (Figure 5). The experiments also showed patterns similar to direct and indirect effects of $\mathrm{CdCl}_{2}$ : - direct since $\mathrm{Cd}^{2+}$ replaces $\mathrm{Ca}^{2+}$ and $\mathrm{Zn}^{2+}$ by mimicking their physiological processes in the cells (Valko et al., 2005), and indirect since $\mathrm{Cd}$ in non-reproductive glands (e.g. the hypothalamus and pituitary) negatively affects reproductive function through suppressed release of FSH and LH (Hoyer et al., 2005). Clinical (Varga et al., 1993) and experimental (Massanyi et al., 2007) data have reported that $\mathrm{Cd}$ accumulates in the testes following oral exposure. Treatment with GB1 offered appreciable protection against $\mathrm{Cd}$ accumulation in this research, compared to the untreated groups. According to the trend of results, three mechanisms may likely be involved in GB1 ability to suppress Cd accumulation in the testes. It is possible that GB1 (a) altered $\mathrm{CdCl}_{2}$ absorption in the gut or (b) enhanced its excretion through the kidneys or (c) acted as an antioxidant in the xenobiotic degradation or excretion of $\mathrm{Cd}$.

It had earlier been reported that Kolaviron (a defatted ethanol extract from $G$. kola seed) elicit its protective action on liver cells by acting as membrane stabilizer (Iwu et al., 1990). However, this does not provide a concrete evidence to prove the "membrane stabilizing" action of the Garcinia hydroxybiflavanonols. Apart from stimulating metabolism in the testicular cells, and scavenging on free radicals, GB1 may also be acting by stabilizing the membranes of the spermatozoa and membranes of 
the Leydig cells which are involved in spermatogenesis. These findings demonstrate that the testicular protective activity of the Garcinia hydroxybiflavanonol-1 (GB1), could be explained, at least in part, by their ability to stabilize the membranes of the spermatozoa and those of cells involved in spermatogenesis.

\subsection{Conclusion}

The study concluded that Garcinia hydroxybiflavanolol-1 ameliorated the deleterious effects of cadmium chloride toxicity on the gonads of male Wistar rats. This stabilizing effect may find a beneficial application in the therapy for various testicular disorders especially those involving abnormal spermatozoa morphology and reduced fragility of the testicular membrane.

\section{Declarations - Conflict of Interest(s)}

Authors declare that they do not have any conflicting interest(s).

\section{References}

Akunna GG, Saalu LC, Ogunlade B, Enye LA (2014) Spermatotoxicity in animal models exposed to fragrance components. Journal of Medical Sciences, 14, pp 46-50.

Alkhedaide A, Alshehri ZS, Sabry A, Abdel-Ghaffar T, Soliman MM, Attia H (2016) Protective effect of grape seed extract against cadmium-induced testicular dysfunction.Molecular Medicine Reports, 13 (4), pp 101-109.

Bu T, Mi Y, Zeng W and Zhang C (2011) Protective effect of quercetin on cadmium-induced oxidative toxicity on germ cells in male mice. Anatomical Record, 294, pp 520-526.

de Angelis C, Galdiero M, Pivonello C, Salzano C, Gianfrilli D, Piscitelli P, \& Pivonello R (2017) The environment and male reproduction: the effect of cadmium exposure on reproductive system and semen quality and its implication in fertility. Reproductive Toxicology, 73. 105-127.

El-Demerdash FM, Yousef MI, Kedwany FS, Baghdadi HH (2004). Cadmium induced changes in lipid peroxidation, blood hematology, biochemical parameters and semenquality of male rats: protective role of vitamin E and b-carotene. Food and Chemical Toxicology, 42 (10), pp 1563-1571.

Farombi E.O., Adedara I.A.,. Oyenihi A.B, Ekakitie E. and Kehinde S. (2013). Hepatic, testicular and spermatozoa antioxidant status in rats chronically treated with G. kola seed. Journal of Ethnopharmacology 146(2): 536-542.

Herron N (2003) Cadmium compounds. In: Kirk-Othmer encyclopedia of chemical technology, vol. 4. Wiley, New York, pp 507-523.

Hoyer PB (2005) Damage to ovarian development and function. Cell and Tissue Research, 322 (1), pp 99-106.

Hussain AR, Owegby GA, Parimoo P, Waterman GP (1982) Kolanone, a novel polyisoprenylated benzophenone with antimicrobial properties from the fruit of Garcinia kola. Planta Medicina, 44, pp 78-81.

Khanna S, Mitra S, Lakhera PC, Khandelwal S (2016) N-acetylcysteine effectively mitigates cadmiuminduced oxidative damage and cell death in Leydig cells in vitro. Drug and Chemical Toxicology, 39 pp 74-80.

Kjellstrom T (1979) Exposure and accumulation of cadmium in populations from Japan, the United States, and Sweden. Environmental Health Perspectives. 28, pp 169-197. 
Madubunyi II (1983) Biochemical and pharmacological studies of the active principles of the seeds of Garcinia kola - Heckel (Guttiferae). Department of Biochemistry, University of Nigeria. M.Sc. Project work. Pp. 196, 204-218.

Cotterhill PJ, Scheinmann F, Stenhouse TA. (1978) Extractives from Guttiferae Kolaflavanone, a new biflavanone from the nuts of Garcinia kola Heckel. Journal of Chemical Society Perkin Transaction 1, 1(6), pp 532-539.

Massanyi P, Lukác N, Uhrin V, Toman R, Pivko J, Rafay J, Forgács Z, Somosy Z (2007) Female reproductive toxicology of cadmium. Acta Biologica Hungarica, 58 (3), pp 287-299.

Massanyi P, Uhrin V, Sirotkin AV, Paksy K, Forgacs ZS, Tomom R, Kovacik J (2000) Effects of cadmium on ultrastructure and steroidogenesis in cultured porcine ovarian granulose cells. Acta Veterinaria Brno, 69, pp101-106.

Massanyi P, Uhrin V, Toman R, Pivko J, Lukac N, Zs F, Somosy Z, Fabis M, Danko J (2005) Ultrastructural changes of ovaries in rabbits following cadmium administration. Acta Veterinaria Brno, 74, pp 29- 35 .

Mendiola J, Moreno JM, Roca M, Vergara-Juarez N, Martinez-Garcia MJ, et al. (2011) Relationships between heavy metal concentrations in three different body fluids and male reproductive parameters: A pilot study. Environmental Health, 10, pp 10-16.

Morrow H (2001) Cadmium and cadmium alloys. In. Kirk-Othmer encyclopedia of chemical technology. Wiley, New York, 471-507. Nutrition Reviews, 52, pp 253-265.

Newairy AA, El-Sharaky AS, Badreldeen MM, Eweda SM, Sheweita SA (2007) The hepatoprotective effects of selenium against cadmium toxicity in rats. Toxicology 242(1), pp 23-30.

Nna VU, Ujah GA, Mohamed M, Etim KB, Igba BO, Augustine ER, Osim EE (2017) Cadmium chloride-induced testicular toxicity in male wistar rats; prophylactic effect of quercetin, and assessment of testicular recovery following cadmium chloride withdrawal. Biomedicine and Pharmacotherapy, 94, pp 109-123.

Nwaehujor CO, Nwinyi FC, Igile GO (2013) The wound healing activities of Garcinia hydroxybiflavanonol (GB1) from Garcinia kola in streptozotocin-induced diabetic rats. International Journal of Biochemistry Photon Foundation. 108, pp 281-287.

Oyeyemi MO, Olukole SG, Ajayi TA, Adeniji DA (2011) Semen characteristics and sperm morphological studies of the West African Dwarf Buck treated with Aloe vera gel extract. Iranian Journal of Reproductive Medicine 9(2), pp 83-88.

Pajavic SB, Saicic ZS (2008) Modulation of antioxidant enzymes activities by sexual steroid hormone. Physiotherapy Research, 57, pp 801-811.

Renugadevi J, Prabu SM (2009) Naringenin protects against cadmium-induced oxidative renal dysfunction in rats. Toxicology, 256(1), pp 128-134.

Roychoudhury S, Massanyi P, Bulla J, Choudhury MD, Lukac N et al (2010) Cadmium toxicity at low concentration on rabbit spermatozoa motility, morphology and membrane integrity in vitro. Journal of Environmental Science and Health, 45, pp 1374-1383.

Sarkar S, Yadov P, Bhatnagar D (1998) Lipid peroxidative damage on cadmium exposureand alterations in antioxidant defence system in rat erythrocytes: a study with relation to time. Bio Metals, 11, pp 153-157.

Sonnenbichler J, Goldberg M, Hane L, Madubunyi I, Vogl S, Zetl I (1986) Stimulatory effect of silibinin on the DNA synthesis in partially hepatectomized rat livers:non -response in hepatoma and other malign cells lines. Biochemistry and Pharmacology, 35 pp 541-544. 
Toman R, Massanyi P, Uhrin V (2002) Changes in the testis and epididymis of rabbits after an inliapcitoneal and peroral administration of cadmium. Trace Elements and Electrolytes 19, pp 114-117.

Uwagie-Ero, E. A., Abiaezute, C. N., Nwaehujor, C. O., Nnaji, T. O., Odigie, E. A., Ekeolu, O. K., \& Ocheja, O. B. (2019). Osteocyte viability and bone density in cadmium chloride-induced osteoporosis ameliorated with Pilostigma thonningii stem bark-extracted D-3-O-methy-chiroinositol. Animal models and experimental medicine, 2(1), pp 25-33.

Valko MM, Morris H, Cronin MTD (2005) Metals, toxicity and oxidative stress. Current Medicinal Chemistry, 12 (10), pp 1161-1208.

Varga B, Zsolnai B, Paksy K, Naray M, Ungvary GY (1993) Age dependent accumulation of cadmium in the human ovary. Reproductive Toxicology, 7 (3) pp 225-228.

Xu LC, Wang SY, Yang XF, Wang XR (2001) Effects of cadmium on rat sperm motility evaluated with computer assisted sperm analysis. Biomedical and Environmental Sciences Research, $14 \quad$ pp 312-317.

Zemjanis R (1977) Diagnostic and Therapeutic technique in animal reproduction. 2nd edition. Williams and Wilkins pp. 139-154.

Zikic RV, Stajn AS, Ognjanovic BI, Saicic ZS, Kostic MM, Pavlovic SZ, Petrovic VM (1998) The effect of cadmium and selenium on the antioxidant enzyme activities in rat heart. Journal of Environmental Pathology Toxicology and Oncology, 17, pp 259-264.

\section{Cite this article as:}

Uwagie-Ero E. A. and Nwaehujor C. O., 2020. Effects of Garcinia hydroxybiflavanonol -1 (GB1) isolated from Garcinia kola Heckel (Guttiferae) seeds on reproductive toxicity induced with cadmium chloride (CdCl2) in male Wistar rats. Nigerian Journal of Environmental Sciences and Technology, 4(1), pp. 21-30. https://doi.org/10.36263/nijest.2020.01.0166 